\section{EDUCATION AND TRAINING FOR ENGINEERS}

O N March 19, 1942, a paper entitled "A Critical Review of Education and Training for Engineers" was read in London before the Institution of Electrical Engineers by Dr. A. P. M. Fleming. The paper was prepared by a sub-committee of the Post-War Planning Committee of the Institution, with Dr. Fleming as its chairman, and it received an extended notice in NATURE of May 2, 1942 (p. 482). Based on this paper and the subsequent discussions, a 22-page report on "Education and Training for Engineers" has now been issued by the Post-War Planning Committee with the authority of the Council of the Institution, with the expressed hope that it may be of assistance to those concerned in the problems of post-war reconstruction in Great Britain.

Dealing first with eraftsmen and foremen, it may be said that there is general agreement on the need for measures which will lead to improvement in the status of the craftsman. To this end the following recommendations are made. More care should be exercised in the selection of entrants to craft training courses. This should be the responsibility of panels representing wider interests and experience than those of the employer alone. There should be a probationary period for all craft apprentices during which provision would be made for transfer to more suitable employ. ment where necessary. The apprenticeship should commence with a period in a special apprentice workshop where the elements of the craft would be acquired under the guidance of experienced instructors. Where possible, these workshops should be a part of the industrial organization, but co-operation of the local technical colleges will be necessary where this is impracticable. Subsequent practical training should be organized, and definite responsibility for the training course should be accepted by each employer. Part-time day release should be granted for general education and for vocational instruction. The combination of workshop and classroom instruction should be organized on nationally recognized lines and a 'craftsman certificate' should be instituted. Subsequent part-time courses should be provided leading to certification for foremanship. The school. leaving age should be raised, and the full-time education received up to this age and the part-time education received afterwards should both be planned on as broad a basis as possible. Thus every facility would be afforded for development, not only in the craft or trade but also in the best use of leisure; and transfer to other types of work would be simplified for the man who so desires.

As to student apprentices, this title is intended to cover those whose practical training and technical education are combined, on a part-time basis, who will become draughtsmen, designers, etc., and may attain some of the highest executive positions. For such it is recommended that organized schemes of practical training should be instituted, or participated in, by all employers of student apprentices, and that recognized national standards should be established. Part-time day release for study, both general and technical, should be compulsory, and this release should be for not less than one full day. per week. Attention to technical matters at the expense of the study of broad scientific principles should not be permitted in the early stages of the course. Some part-time evening instruction should also be available, but this should not be made compulsory. The present schemes of Ordinary and Higher National Certificates shoúld be continued and developed and should form an integral part of student apprenticeship. Consideration should be given to making teaching in technical schools, institutes and colleges more attractive as a profession. The facilities which are available for technical teachers to return to industry for short periods, to renew their industrial experience, should be extended. Technical teachers should receive instruction in the art of teaching.

For university trainees it is recommended that full-time university courses should be made available to anyone who has the ability to obtain full benefit from them. There must be no financial barrier to entry. Schemes similar to the present State bursary scheme should be implemented after the War, provision being made for increased transfer from National Certificate to university courses. University engineering schools should cease to treat all students as potential high-grade scientific or technical workers ; those who are not should receive instruction in economics, law and social science in place of the more advanced technical instruction. It is the duty of the university to equip men for leadership and not merely to impart advanced technical and scientific knowledge. University engineering students should devote part of the two shorter vacation periods to tutorial classes and part of the longer vacation period to the acquisition of practical experience. A period of the order of one year should be spent in gaining experience of industry before proceeding from school to the university. All university engineering graduates should be given a course of practical training of a broad character.

Lastly, in respect of 'post-advanced students it should be remarked that the professional engineer must acquire specialized knowledge of the branch of engineering in which he is engaged, and the university graduate must acquire practical experience before he is able to apply his academic knowledge usefully. To this end it is recommended that postgraduate work at universities should be further developed, and that 'post-advanced' courses of lectures by recognized authorities should be provided locally on specialized branches of engineering practice. Technical colleges should extend the provision of 'post: advanced' courses in such subjects as economics, workshop organization and management, industrial management and business practice. These and similar subjects should be studied when the student is sufticiently mature to appreciate them and is likely to be able to make use of them. This is particularly important in the training of men who have been selected as potential executives. Such men should also be afforded opportunities of acquiring experience in administration.

Subsequent to the above recommendations, the report presents the bases upon which they are made, these being as follows: an outline of the pre-war engineering education and training system for England and Wales, and the essential elements of a satisfactory post-war system, which latter embody vocational guidance and selection, training of engineers, training of craftsmen, and the selection and training of teachers.

In its concluding paragraph, the report strikes the real keynote of success, urging that "the progress of engineering - in fact that of any human activitydepends on personnel. It is therefore essential 
in the national interest to secure the proper recruitment and training of personnel for the engineering industry, not only for the higher professional ranks but also for every grade of worker. It should be a fundamental principle in dealing with engineering personnel to ensure that every individual is so trained that, whatever the work on which he is employed, he can give service in the most efficient manner possible".

\section{SCIENCE IN SOVIET RUSSIA}

$\mathrm{I}^{\mathrm{N}}$ $\mathrm{N}$ his account of "Science in Soviet Russia", in the Trueman Wood Lecture before the Royal Society of Arts on April 14, Mr. J. G. Crowther said that the place of science in Soviet philosophy is the most important motive in the development of science in the Soviet Union.

Reviewing the development of the new physical research institutes, Mr. Crowther pointed out that these were not built until the men to run them had already been trained. Following that of the Ukraine opened at Kharkov in 1930, others were founded at Dniepropetrovsk, Sverdlovsk, Tiflis and other centres. The existence of these new scientific institutes, especially in the east, has been of great importance during the present War. Sverdlovsk, for example, received important sections of the Soviet Academy of Sciences when Moscow was threatened. The new institutes have special lines of research appropriate to the needs of the locality. The Physico-Technical Institute at Kharkov had large research departments in high-tension physics and low-temperature physics. At Dniepropetrovsk and Sverdlovsk, special attention was given to metallurgy, the latter Institute serving the scientific needs of the metal industry of the Urals.

In the planned development of science in the U.S.S.R., Mr. Crowther said that at least as much importance is attached to human as to natural resources, and the founding of special institutes for men of outstanding ability has been a feature of it. In such planning, the importance of the Academy of Sciences has steadily increased and it is now directly responsible for this work to the Supreme Soviet. The Academy determines the general lines of scientific work in accordance with the needs of the State and possibilities in subjects and personalities. It sees that balanced attention is given to all sides of science, that no important branches are neglected and overlapping is reduced. Moreover, such planning is a mutual process of adjustment in which ideas flow equally from the top and the bottom.

The plan of research for 1943 is mainly directed to the improvement of war industries and armaments (see Nature, January 30, p. 129). Geologists and geographers are engaged on the exploration and study of new sources of oil, ores and minerals, especially in the Urals, West Siberia, Kazakhstan and the Middle Volga regions. Agricultural science will be devoted to efforts to increase the yield of cereal and industrial crops such as rubber-bearing plants, potatoes and beet. Technologists are to develop the use of industrial gas and the gasification of new forms of fuel, so that local fuels can be utilized and long hauls reduced, in addition to research on aircraft, radio, weapons, etc.

After a brief account of some of the achievements of Soviet science, Mr. Crowther said that the spirit of the Soviet men of science rather than the impressive number and equipment of Soviet scientific institu- tions is the chief quality of Soviet science. The atmosphere of youth is striking and the planning of the research and the relation of the work of the Institutes to industrial and political affairs are the subject of continuous organized discussion. One of the achievements of Soviet technology has been the provision of an immense body of good technical officers for the Red Army. The problem of social relations between the scientific and the ordinary worker has largely been solved, and the scientific worker has great prestige due to philosophical and practical reasons, and he is relatively well paid, enjoying also special holiday facilities as well as the health and education services available to every Soviet citizen.

\section{TIMIRIAZEV CENTENARY CELEBRATIONS}

$\mathrm{O}^{\mathrm{N}}$ $\mathrm{N}$ June 3, the hundredth anniversary of the birth of the Russian naturalist and plant physiologist, Klimenty Timiriazev, was celebrated throughout the Soviet Union, special celebrations being held in Moscow.

Timiriazev was a member of an impoverished noble family living in St. Petersburg. The interest which Darwinism excited in him while he was a student persisted throughout his life. In 1864 he published three articles about Charles Darwin and his teachings. In 1870 he was elected to the chair of botany at St. Petersburg Agricultural Academy and in 1877 he became, in addition, professor in the University of Moscow, where he lectured on the anatomy and physiology of plants. He was the author of many scientific works which have now been issued as a twelve-volume complete edition. Timiriazev devoted fifty years of scientific activity to the study of photosynthesis. His work was marked by exactitude, perfection being his constant aim, and his improvements in technique won the admiration of many scientific men.

The main problem of Timiriazev's scientific work was the occurrence of photosynthesis in relation to regions of the solar spectrum-a problem further worked on by A. Richter, V. Lubimenko, and A. Danilov. Timiriazev established the fact that disintegration of carbon dioxide proceeds most inten. sively under the influence of red light. Proceeding from the principle that accumulation of dry plant matter reaches its maximum in the blue regions of the spectrum, Danilov has extended Timiriazev's work to show certain relationships in aquatic plants. Timiriazev was also interested in the pigmentary apparatus of photosynthesis. $\mathrm{He}$ also investigated field ecology; and the urge that incited even his most academic work was the practical aim of helping the farmer, and thereby the people at large.

Timiriazev lived to see only the first two years of the Soviet Revolution, of which he declared himself to be a warm supporter. He not only left several brilliant students including Dmitri Prianishnikov, Sergei Kostichev, and his son Prof. Arkady Timiriazev, but also acquired a remarkable reputation throughout Russia as a popularizer of science. Maxim Gorky asked how it was that in some snowy hamlet of the Kherson province, or so far away as Perm, Timiriazev was known, and his books frequently asked for. Timiriazev's support of the Darwinian theory has ensured popularity for it in Russia. 